\title{
MODERATING EFFECT OF NATIONAL ORIGIN ON RELATIONSHIP OF ORGANIZATIONAL CULTURE AND JOB SATISFACTION
}

\author{
UDC: $005.32: 331.101 .32$ \\ 005.73:331.101.32 \\ Original Scientific Paper \\ Jelena VUKONJANSKI ${ }^{1}$, Milan NIKOLIĆ ${ }^{2}$ \\ ${ }^{1}$ University of Novi Sad, Technical faculty "Mihajlo Pupin” Zrenjanin, 23000 Zrenjanin, Đure Đakovića bb, \\ Republic of Serbia. E-mail: jelena.vukonjanski@gmail.com \\ ${ }^{2}$ University of Novi Sad, Technical faculty "Mihajlo Pupin” Zrenjanin, 23000 Zrenjanin, Đure Đakovića bb, \\ Republic of Serbia
}

Paper received: 20.03.2014.; Paper accepted: 27.05.2014.

\begin{abstract}
This paper represents results research of moderating effect of national origin of companies on relationship of organizational culture (according to Globe project), and dimensions of job satisfaction. The research included 256 middle managers who work in domestic (183) and 73 managers who work in foreign companies in Serbia. Relations between some organizational culture dimensions and facets of job satisfaction are moderated by the national origin of companies. Managers are given directions in starting appropriate activities oriented towards changes in organizational culture in their companies through explanation of relationship of OC and JS in order to improve organizational results.
\end{abstract}

Keywords: organizational culture, job satisfaction, national origin of companies.

\section{INTRODUCTION}

The last two decades are the time of political and economic changes in many Eastern European countries including Serbia. After wars, economic sanctions, one of the highest hyperinflations in the world (Hanke and Krus, 2012:12), NATO aggression, economics, politics and social changes, privatization, Serbia has a transitional economy mostly dominated by services, manufacturing and agriculture. The economy is heavily reliant on exports and foreign investment. According to Blyton (2001) common political projects such as achieving trade liberalization and privatization of state-owned enterprises have provided a key element in the platform of economic globalization. In addition, common political programs, power and mobility of transnational capital and their impact on the national economic systems are comprehensive evidence that social systems fundamentally converge in terms of the functioning of the regulatory system and the functioning of organizations. The author states that despite of the above mentioned processes of convergence national differences are moderating factors which influence the way societies and organizations work.

Organizational culture is determined by organization's dominating values (Deal and Kennedy, 1982; Lauzen and Dozier, 1994) accepted by majority of employees (Wallack, 1983), as well as common norms and beliefs of organization's members (Kroeber et al., 1952; Schein, 1985, 1990; Kotter, 1992, 1996; Conner, 1992; Cummings and Worley, 2005). It is in a certain sense a philosophy that determines organizational policy towards internal and external surroundings (Pascale and Athos, 1981).

Smith (1992) investigates the degree to which organizational behaviour is found to vary between national cultures. He concludes that there is an increasing need to prepare managers for multicultural experience. National culture can be an important variable that influences the development of cognitive style and decision making process of managers (Dimitratos et al., 2011). According to Brooks (2006:271-295), national culture can affect the relationship between 
managers of different nationalities and cultures when they need to work together. Pasa, Kabasakal and Bodur (2001) state that some other differences between developed countries and developing countries are also an important factor for the development of some specific ways of management. According to the authors, the developing countries are located in East and West Africa, Central and Latin America, the Middle East and in some parts of Eastern Europe and they have many characteristics that vary in intensity, such as underdeveloped infrastructure, abundance of unskilled labor, low technological development, political instability, rigid social structure, gender differences, and strong influence of tradition. Berry and Ward (2006) suggested that the encounter of individuals from different cultures often results in stress that can grow to a conflict. Ward, Bochner and Furnham (2001), in their book which is dedicated to the importance of culture shock, suggested that the understanding of how management practices and national culture are connected was at the very beginning, although there were studies which deal with that relationship. But the authors considered these results as unreliable and limited because they rely mostly on Hofstede (1980, 2001:176) studies which they considered as obsolete.

Feichtinger and Fink (1998) found that the process of cultural change and its characteristics in the transition countries that have communist legacy produce a "culture shock" as a result of confrontations to foreign cultures, and that a collective culture shock affects the management and business relationships and creating problems. In transition countries, culture shock is the product of complex economic, social and political forces and Fink and Holden (2002) consider this phenomenon as an important conceptual tool for managers who are responsible for international strategy in transition countries. According to Brooks (2006:285), culture shift is also important and represents degree to which culture can change and speed up changes. Numerous factors can affect culture shift, such as economic conditions, increase of foreign investments, sudden social, politics and religious changes.

Dickson (2003) believes that Javidan and House (2001) presented convincing arguments for the work on the GLOBE project since global managers have to be sensitive to cultural differences among employees. In addition, the GLOBE project provides relevant information for the creation of cross cultural communication, and the lessons of the project can serve as a starting point for the development of interpersonal and cultural needs of global managers. For researchers to understand culture they need to assess the broader cultural paradigm of a society within which the organization operates since this influences the manner in which the organization operates (Javidan and House, 2001; Gerhart, 2008). Denison (1996) notes that a fundamental dilemma which is often faced in the literature on organizational culture is that theories tend to posit that individuals influence an organizational culture, and that they are also influenced by the organizational culture. While micro-level theories might equate organizational culture with an employee's perceptions of an organization, in order for those perceptions to be truly "organizational," they must be based on a common environmental stimulus present in the organization. Organizational cultures partly develop in response to stimuli that are experienced in common by organizational members.

\section{ORGANIZATIONAL CULTURE AND JOB SATISFACTION}

\section{Organizational culture}

Organizational culture is determined by organization's dominating values (Deal and Kennedy, 1982; Lauzen and Dozier, 1994) accepted by majority of employees (Wallack, 1983), as well as common norms and beliefs of organization's members (Kroeber et al., 1952; Schein, 1985, 1990; Kotter, 1992; Kotter \& Heskett, 1996; Conner, 1992; Cummings and Worley, 2005). It is in a certain sense a philosophy that determines organizational policy towards internal and external surroundings (Pascale and Athos, 1981).

Organizational culture exists on cognitive and emotional level and represents set of basic assumptions, values, attitudes and norms of behavior shared within an organization and manifested through their members' perceptions, thoughts, feelings and behavior, as well as artifacts of both a material and nonmaterial nature (Deal and Kennedy, 1982; Lauzen and Dozier, 1994; Wallack, 1983; Schein, 1985; Kotter and Heskett 1992; Conner, 1992; House et al. 1997).

According to Hofstede (1991), culture is software of the mind, which distinguishes the members of one group or category of people from another. Culture is a collective oriented phenomenon and 
refers to shared meanings and cultural norms and cultural variables which have a strong influence on the social and organizational activities as members of the collective posses shared values and social identity (House, Wright and Aditya, 1997). Due to globalization and increased dependence among nations the growing interest in understanding national cultures (House, Javidan and Dorfman, 2001) enhance cross -cultural management investigations.

Organizational culture influences all aspects of business and life in a company. It is linked to numerous organizational results (House at al., 2004), and one of them is job satisfaction. Connecting individual aims of employees to aims of the organization and reliance on responsibility of employees are the factors of organizational culture successfulness (Morgan, 1977). Organizational culture is also one of significant factors of job satisfaction (Moynihan and Pandey, 2007).

\section{Job satisfaction}

Although job satisfaction is more an attitude than behaviour many managers expect results because satisfied workers will come to work more regularly and stay in the company longer. (Robins and Coulter, 2005). It can be concluded that job satisfaction in certain extent represents an indicator of employees' perception about organizational culture of their company (Sempane, Rieger and Roodt, 2002). Spector (1997) says that job satisfaction is no doubt most researched variable in Industrial and Organizational Psychology. Job satisfaction is related to general attitude of individuals to their job. Affective dimension of job satisfaction is defined as satisfying or positive emotional state which results from estimation of a job or work experience (Locke, 1976:1302-1304). Emloyees' job satisfaction influences their mental health, longevity, emotional life as a whole (Locke, 1976: 1311; Sempane, Rieger and Roodt, 2002). Job dissatisfaction can significantly influence behaviour of employees which results in absence from work, complaints and termination of employment.

A great number of researchers examine the relationship of job satisfaction and organizational culture (Judge et al., 2001; Sempane, Rieger and Roodt, 2002; Moynihan and Pandey, 2007; Spector, 1997; Meyer et al., 2002; Lund, 2003; Silverthorne, 2004; Fargher et al., 2008; Amos and Weathington, 2008; Bellou, 2010). When it comes to companies in Serbia, reasearch (Vukonjanski et al., 2012) has shown, that organizational culture has significant effect on job satisfaction of emnployees.

On the grounds of the mentioned above the following hypothesis is derived:

$\mathrm{H}$ : National origin of companies has moderating effect on relationship of dimensions of organizational culture and job satisfaction in Serbian companies.

\section{RESEARCH METHODOLOGY}

\section{Respondents and data collecting}

The research lasted for 5 months and it was carried out from 1st January to 1st June, 2011. During this period collecting of questionnaires was carried out through interviewing respondents. Responses were got from 256 middle managers from 131 companies and the sample was chosen to provide both, domestic and foreign companies (183 employees in domestic and 73 in foreign companies). The research was carried out in companies in Serbia, no matter the branch of industry, but in companies with more than 50 employees. Namely, in the companies with a small number of employees there are only a few managers on the same level and the owner is not a supervisor to managers in a classical sense, in other words, owners do not have previous experience in management and are not fully involved in management process. All respondents in the sample have Bachelor or Master degree and according to sex, 136 are male and 120 female. Out of the total number of respondents, 134 are employed in public and 122 in foreign companies in Serbia.

\section{Research instruments}

In the research was used the instrument of Globe project, precisely the first part of Alfa questionnaire which includes the questions related to organizational culture, the state "'as it is" and it is consisted of 34 questions. Respondents marked the values on the scale from 1 to 7 and the filled-in questionnaires were processed according to Globe Syntax. The instrument measures 9 organizational and national dimensions and the dimensions are: avoiding uncertainty, orientation to the future, power distance, institutional collectivism, orientation to people, orientation to performances, 
collectivism within the group, gender equality, assertiveness (House et al. 1999, 2002, 2004).

Questionnaire for measuring job satisfaction was applied for measuring job satisfaction. The questionnaire JS is consisted of 36 items which are valued from 1 to 6 and 9 scales which estimate attitudes of employees about the job and its aspects: salary, promotion, supervision, benefits, rewards, operation procedures, co-workers, the nature of job, communication (Spector, 1985). Significance of each of these scales is different in some extent and the result is in different importance in cases of evaluation of total job satisfaction (Spector, 1997).

\section{Data analysis}

Data has been processed in accordance to applied instruments for measuring dimensions of organizational culture and job satisfaction. Internal consistency of scales was confirmed. Descriptive statistics and correlation analysis of the relationship of organizational culture and job satisfaction were used and then the relationship of organizational culture and job satisfaction was observed with moderator "ownership structure of the company". In order to determine the connection between dimensions of Globe organizational culture, job satisfaction and ownership structure in Serbian companies we used hierarchical and regression analysis (Milin and Hadžić 2011) and Chow test (Chow, 1960) with the aim to examine moderating influence of ownership structure on regression between JS (as dependent variable) and $\mathrm{OC}$ (as independent variable), whereas $i, j=1,2,3,4,5,6,7,8,9$.

\section{RESEARCH RESULTS}

In the Table 1. The results of Descriptive analysis are presented (mean values and standard deviations) for dimensions of the state of organizational culture "'as it is" and job satisfaction dimension. A short name of dimensions which will be used in future discussion is also given in the Table. The values skewness and kurtosis presented in the Table point at normal distribution of score for all scales.

Table 1: Descriptive statistics for the relation between dimensions of organizational culture and job satisfaction in the companies in Serbia

\begin{tabular}{|c|c|c|c|c|c|c|c|}
\hline & \multirow{2}{*}{$\begin{array}{l}\text { Short } \\
\text { name }\end{array}$} & \multirow{2}{*}{ Mean } & \multirow{2}{*}{ SD } & \multicolumn{2}{|c|}{ Skewness } & \multicolumn{2}{c|}{ Kurtosis } \\
\cline { 5 - 8 } & & & Stat. & $\begin{array}{c}\text { Std. } \\
\text { Error }\end{array}$ & Stat. & $\begin{array}{c}\text { Std. } \\
\text { Error }\end{array}$ \\
\hline Uncertainty Avoidance & OC1 & 3.8006 & 1.34038 & .107 & .163 & -.013 & .324 \\
\hline Future Oriented & OC2 & 4.3080 & 1.63478 & -.213 & .163 & -.814 & .324 \\
\hline Power Distance & OC3 & 4.7946 & 1.42911 & -.264 & .163 & -.660 & .324 \\
\hline Collectivism 1 & OC4 & 3.8199 & 1.35587 & -.008 & .163 & -.510 & .324 \\
\hline Humane Orientation & OC5 & 4.2232 & 1.41515 & -.088 & .163 & -.490 & .324 \\
\hline Performance Orientation & OC6 & 3.9408 & 1.36935 & -.001 & .163 & -.632 & .324 \\
\hline Collectivism 2 & OC7 & 4.5634 & 1.18553 & -.177 & .163 & -.264 & .324 \\
\hline Gender Egalitarianism & OC8 & 2.9301 & 1.20891 & .294 & .163 & -.103 & .324 \\
\hline Assertiveness & OC9 & 3.7656 & 1.09026 & -.074 & .163 & 1.166 & .324 \\
\hline Pay & JS1 & 2.9107 & 1.32451 & .343 & .163 & -.809 & .324 \\
\hline Promotion & JS2 & 3.3304 & 1.18838 & -.009 & .163 & -.229 & .324 \\
\hline Supervision & JS3 & 3.6641 & 1.29293 & -.030 & .163 & -.705 & .324 \\
\hline Fringe Benefits & JS4 & 2.9989 & 1.25291 & .361 & .163 & -.545 & .324 \\
\hline Contingent Rewards & JS5 & 3.1529 & 1.35047 & .447 & .163 & -.522 & .324 \\
\hline Operating Procedures & JS6 & 3.1830 & 1.04199 & .233 & .163 & .620 & .324 \\
\hline Coworkers & JS7 & 4.3571 & 1.13777 & -.562 & .163 & .217 & .324 \\
\hline Nature of Work & JS8 & 4.4900 & 1.23553 & -.874 & .163 & .374 & .324 \\
\hline Communication & JS9 & 3.9699 & 1.31775 & -.185 & .163 & -.832 & .324 \\
\hline
\end{tabular}


Table 2: Relation between OCi and JSj in D and F sub-groups

\begin{tabular}{|c|c|c|c|c|c|c|c|c|c|c|c|c|c|c|c|c|c|c|}
\hline \multirow{2}{*}{$\begin{array}{c}\text { National } \\
\text { origin of } \\
\text { companies }\end{array}$} & \multicolumn{2}{|c|}{ JS1 } & \multicolumn{2}{|c|}{ JS2 } & \multicolumn{2}{|c|}{ JS3 } & \multicolumn{2}{|c|}{ JS4 } & \multicolumn{2}{|c|}{ JS5 } & \multicolumn{2}{|c|}{ JS6 } & \multicolumn{2}{|c|}{ JS7 } & \multicolumn{2}{|c|}{ JS8 } & \multicolumn{2}{|c|}{ JS9 } \\
\hline & D & $\mathrm{F}$ & D & $\mathrm{F}$ & D & $\mathrm{F}$ & D & $\mathrm{F}$ & D & $\mathrm{F}$ & D & $\mathrm{F}$ & D & $S$ & $\mathrm{D}$ & $S$ & D & $S$ \\
\hline OC1 & $.408^{* *}$ & -.106 & $.398^{* * *}$ & -.157 & $.271^{* * *}$ & .213 & $.295^{* *}$ & -.087 & $.324^{* * *}$ & -.168 & -.027 & $.393^{*}$ & $.259^{* * *}$ & -.164 & $.201^{* * *}$ & -.141 & $.429^{* *}$ & .058 \\
\hline OC2 & $.481^{\text {** }}$ & $.617^{* *}$ & $.449^{* *}$ & $.417^{\text {** }}$ & $.385^{* *}$ & $.529^{* *}$ & $.431^{* *}$ & $.319^{*}$ & $.471^{* *}$ & $.458^{* *}$ & $-.178^{*}$ & $-.338^{*}$ & $.390^{* *}$ & $.533^{* *}$ & $.287^{* *}$ & $.408^{* *}$ & $.539^{* * *}$ & $.446^{* *}$ \\
\hline OC3 & $-.376^{* *}$ & $-.546^{* *}$ & $-.400^{* *}$ & -.257 & $-.348^{* *}$ & $-.327^{*}$ & $-.299^{* *}$ & -.276 & $-.381^{* *}$ & $-.443^{* *}$ & $.216^{* *}$ & .009 & $-.269^{* * *}$ & -.219 & $-.218^{* * *}$ & -.222 & $-.455^{* *}$ & $-.334^{*}$ \\
\hline OC4 & $.359^{\text {** }}$ & $.381^{*}$ & $.316^{* * *}$ & $.457^{* *}$ & $.172^{*}$ & $.379^{*}$ & $.184^{*}$ & $.511^{\text {** }}$ & $.368^{* * *}$ & $.497^{\text {** }}$ & -.088 & .107 & $.253^{* *}$ & $.337^{*}$ & $.171^{*}$ & .131 & $.316^{* *}$ & .298 \\
\hline OC5 & $.457^{\text {** }}$ & $.614^{* * *}$ & $.406^{* *}$ & $.593^{\text {** }}$ & $.349^{* * *}$ & $.491^{* *}$ & $.301^{* *}$ & $.530^{* * *}$ & $.452^{* *}$ & $.555^{\text {** }}$ & $-.190^{* *}$ & .047 & $.494^{* *}$ & $.523^{* *}$ & $.359^{* *}$ & $.363^{*}$ & $.517^{* *}$ & $.374^{*}$ \\
\hline OC6 & $.609^{* *}$ & $.695^{* * *}$ & $.575^{\text {** }}$ & $.536^{* *}$ & $.468^{* *}$ & $.600^{* *}$ & $.401^{* *}$ & $.679^{\text {*** }}$ & $.610^{* * *}$ & $.690^{* * *}$ & $-.184^{*}$ & -.103 & $.441^{* *}$ & $.481^{* *}$ & $.368^{* *}$ & $.381^{*}$ & $.610^{* *}$ & $.597^{* *}$ \\
\hline OC7 & $.530^{* * *}$ & $.769^{\text {** }}$ & $.477^{* * *}$ & $.499^{* *}$ & $.448^{* *}$ & $.596^{* * *}$ & $.425^{* *}$ & $.705^{* *}$ & $.489^{* * *}$ & $.739^{* * *}$ & $-.219^{* *}$ & -.098 & $.468^{* *}$ & $.528^{* *}$ & $.436^{* *}$ & $.447^{* *}$ & $.555^{* *}$ & $.706^{* *}$ \\
\hline OC8 & .077 & -.137 & .045 & .125 & $.169^{*}$ & -.163 & .130 & .104 & $.152^{*}$ & .029 & -.124 & -.147 & .011 & .035 & .055 & -.022 & $.197^{* *}$ & -.072 \\
\hline OC9 & -.073 & .167 & .017 & .155 & -.024 & .058 & -.137 & .220 & -.129 & .077 & -.014 & -.160 & -.109 & .042 & -.075 & .184 & $-.160^{*}$ & .202 \\
\hline
\end{tabular}

**p $<0.01 ; * \mathrm{p}<0.05$ 
Table 3: Chow test results for sub-groups $D$ and $F$

\begin{tabular}{|c|c|c|c|c|c|c|c|c|c|c|}
\hline \multicolumn{2}{|c|}{$\begin{array}{l}\text { National } \\
\text { origin of } \\
\text { companies }\end{array}$} & JS1 & JS2 & JS3 & JS4 & JS5 & JS6 & JS7 & JS8 & JS9 \\
\hline \multirow{4}{*}{$\mathrm{OC} 1$} & RS & 349.187 & 290.545 & 347.576 & 331.766 & 385.462 & 241.785 & 280.199 & 334.531 & 334.040 \\
\hline & RSD & 260.846 & 215.587 & 288.604 & 273.060 & 290.815 & 206.281 & 219.092 & 265.041 & 264.635 \\
\hline & RSF & 69.653 & 57.287 & 58.287 & 50.373 & 78.741 & 29.913 & 52.404 & 62.916 & 59.784 \\
\hline & $\mathrm{F}$ & 7.125 & 8.160 & 0.249 & 3.246 & 5.423 & 2.983 & 4.039 & 2.526 & 3.737 \\
\hline \multirow{4}{*}{ OC2 } & RS & 289.195 & 254.064 & 309.406 & 291.286 & 316.944 & 231.658 & 238.349 & 307.593 & 281.244 \\
\hline & RSD & 240.643 & 204.473 & 265.180 & 243.566 & 252.740 & 199.865 & 199.022 & 253.488 & 230.060 \\
\hline & RSF & 43.628 & 48.496 & 43.975 & 45.604 & 64.039 & 31.324 & 38.572 & 53.526 & 48.059 \\
\hline & $\mathrm{F}$ & 2.183 & 0.545 & 0.102 & 0.922 & 0.066 & 0.256 & 0.400 & 0.238 & 1.416 \\
\hline \multirow{4}{*}{ OC3 } & RS & 325.609 & 271.861 & 328.747 & 319.679 & 343.271 & 234.347 & 269.386 & 324.096 & 314.795 \\
\hline & RSD & 268.823 & 215.130 & 273.724 & 272.251 & 277.600 & 196.804 & 217.831 & 263.056 & 257.210 \\
\hline & RSF & 49.410 & 54.848 & 54.543 & 46.886 & 65.136 & 35.369 & 51.270 & 61.017 & 53.279 \\
\hline & $\mathrm{F}$ & 2.920 & 0.879 & 0.184 & 0.214 & 0.197 & 1.180 & 0.133 & 0.009 & 1.747 \\
\hline \multirow{4}{*}{ OC4 } & RS & 339.291 & 277.980 & 356.286 & 329.660 & 343.210 & 241.399 & 267.738 & 331.409 & 349.100 \\
\hline & RSD & 272.689 & 230.483 & 302.241 & 288.902 & 280.949 & 204.845 & 219.751 & 268.191 & 292.032 \\
\hline & RSF & 60.225 & 46.467 & 52.299 & 37.495 & 60.994 & 34.966 & 47.751 & 63.080 & 54.656 \\
\hline & $\mathrm{F}$ & 2.414 & 0.469 & 0.621 & 1.260 & 0.467 & 0.834 & 0.111 & 0.052 & 0.877 \\
\hline \multirow{4}{*}{ OC5 } & RS & 304.345 & 253.795 & 321.569 & 310.717 & 317.821 & 236.711 & 216.818 & 296.447 & 295.973 \\
\hline & RSD & 247.755 & 213.792 & 273.476 & 271.976 & 258.453 & 198.975 & 177.419 & 240.558 & 237.799 \\
\hline & RSF & 43.911 & 38.066 & 46.358 & 36.513 & 56.077 & 35.295 & 39.143 & 55.710 & 51.580 \\
\hline & $\mathrm{F}$ & \begin{tabular}{|l}
5.477 \\
\end{tabular} & 0.969 & 0.684 & 0.910 & 1.318 & 1.313 & 0.149 & 0.076 & 2.871 \\
\hline \multirow{4}{*}{ OC6 } & RS & 238.134 & 214.302 & 282.675 & 279.941 & 246.865 & 234.998 & 230.866 & 293.798 & 243.934 \\
\hline & RSD & 196.956 & 171.411 & 243.334 & 251.063 & 203.913 & 199.415 & 189.226 & 238.815 & 203.582 \\
\hline & RSF & 36.389 & 41.854 & 39.077 & 27.359 & 42.481 & 34.998 & 41.403 & 54.876 & 38.629 \\
\hline & $F$ & 2.586 & 0.613 & 0.118 & 0.687 & 0.241 & 0.314 & 0.129 & 0.046 & 0.896 \\
\hline \multirow{4}{*}{ OC7 } & RS & 270.553 & 242.219 & 290.700 & 274.255 & 292.845 & 232.661 & 222.859 & 275.428 & 261.387 \\
\hline & RSD & 252.111 & 197.903 & 248.923 & 245.033 & 247.225 & 196.499 & 183.401 & 223.676 & 224.660 \\
\hline & RSF & 28.802 & 44.132 & 39.353 & 25.549 & 36.816 & 35.032 & 38.852 & 51.344 & 30.062 \\
\hline & $\mathrm{F}$ & -4.647 & 0.096 & 1.059 & 1.710 & 3.905 & 0.615 & 0.344 & 0.187 & $\mathbf{3 . 2 9 7}$ \\
\hline \multirow{4}{*}{ OC8 } & RS & 389.517 & 313.997 & 368.297 & 344.415 & 399.465 & 237.890 & 288.621 & 339.902 & 377.079 \\
\hline & RSD & 311.144 & 255.518 & 302.484 & 294.052 & 317.325 & 203.276 & 234.787 & 275.381 & 311.872 \\
\hline & RSF & 69.115 & 57.806 & 59.444 & 50.201 & 80.955 & 34.605 & 53.794 & 64.155 & 59.680 \\
\hline & $\mathrm{F}$ & 3.068 & 0.271 & 2.217 & 0.059 & 0.375 & 0.005 & 0.017 & 0.136 & 1.874 \\
\hline \multirow{4}{*}{ OC9 } & RS & 391.138 & 314.399 & 372.766 & 348.132 & 403.866 & 241.693 & 286.800 & 340.201 & 384.259 \\
\hline & RSD & 311.299 & 255.970 & 311.217 & 293.444 & 319.471 & 206.390 & 232.009 & 274.687 & 316.131 \\
\hline & RSF & 68.482 & 57.319 & 60.853 & 48.299 & 80.541 & 34.471 & 53.767 & 62.015 & 57.531 \\
\hline & $\mathrm{F}$ & 3.768 & 0.446 & 0.236 & 2.356 & 1.214 & 0.435 & 0.451 & 1.309 & 3.573 \\
\hline
\end{tabular}

Table 4: Hierarchical regression analysis for ownership structure of company ( $R$ square $i$ F changes)

\begin{tabular}{|c|c|c|c|}
\hline Independent & Dependent & R square & F-change \\
\hline \multirow{4}{*}{ OC1 } & JS1 & .155 & 10.962 \\
\cline { 2 - 4 } & JS2 & .134 & 12.567 \\
\cline { 2 - 4 } & JS4 & .076 & 5.557 \\
\cline { 2 - 4 } & JS5 & .091 & 9.467 \\
\cline { 2 - 4 } & JS6 & .024 & 4.756 \\
\cline { 2 - 4 } & JS7 & .060 & 6.676 \\
\cline { 2 - 4 } & JS8 & .037 & 4.255 \\
\cline { 2 - 4 } & JS9 & .162 & 6.501 \\
\hline \multirow{4}{*}{ OC7 } & JS1 & .351 & 3.827 \\
\cline { 2 - 4 } & JS5 & .302 & 4.876 \\
\hline \multirow{2}{*}{ OC8 } & JS3 & .029 & 3.869 \\
\cline { 2 - 4 } & JS9 & .040 & 2.738 \\
\hline \multirow{3}{*}{ OC9 } & JS4 & .024 & 3.865 \\
\cline { 2 - 4 } & JS8 & .011 & 2.283 \\
\cline { 2 - 4 } & JS9 & .035 & 4.208 \\
\hline
\end{tabular}

Table 2. presents Pirson's coefficients of correlation $\mathrm{OCi}$ and $\mathrm{JSj}$ for $\mathrm{D}$ (domestic) and $\mathrm{F}$ (foreign) companies in Serbia, for every $i, j=1,2$, $3,4,5,6,7,8,9$. In domestic companies in Serbia correlation between organizational culture and job satisfaction is more significant. OC1 and JSj are significantly different in domestic and foreign companies. Correlation is statistically significant in domestic companies, and in relation of OC1 i JS6 in foreign companies. 
OC3 has more significant relation in domestic and foreign companies in correlation with JS2, JS3, JS4, JS6, JS7, JS8, JS9. OC8 has more significant relation in domestic companies in correlation with JS3, JS5 and JS9. Chow test results for differences of regression coefficients for regression between $\mathrm{OCi}$ and $\mathrm{JSj}$ for sub-groups domestic and foreign companies are presented in Table 3.

The results of hierarchical regression analysis are presented in Table 4., and the results of $\mathrm{R}$ square and $\mathrm{F}$ changes which are statistically significant and support $\mathrm{H}(\mathrm{OCi}, \mathrm{JSj})$ regressions for sub-groups $\mathrm{D}$ (domestic) and $\mathrm{F}$ (foreign) companies.

\section{DISCUSSION OF RESULTS}

Increase of $\mathrm{OC} 1$ is followed by faster increase of negative effect JS1, JS2, JS4, JS5, JS7 and JS8 in sub-group F, but coefficients are not significant and JS6 is not significantly different from zero in sub-group D. According to the results of Chow test, national origin of companies is a moderator of a relation $\mathrm{OC} 1$ and JS1 $(\mathrm{F}=7.125), \mathrm{JS} 2(\mathrm{~F}=8.160)$, JS4 ( $\mathrm{F}=3.246)$, JS5 ( $\mathrm{F}=5.423)$, JS6 ( $\mathrm{F}=2.983)$, JS7 $(\mathrm{F}=4.039)$, JS8 $(\mathrm{F}=2.526)$ and JS9 $(\mathrm{F}=3.737)$. Hierarchical regression analysis has confirmed moderating effect for all JSj, except JS3. Reliance on rules and regulations, risk avoidance, work without initiative and work according to superiors to middle managers in sub-group $\mathrm{D}$ increase satisfaction with pay, promotion, benefits, rewards, coworkers, nature of work, communication. It also, leads to increase of negative effect operative procedures. Results of analysis are expected, and they confirm that Serbia tend to high degree of uncertainty avoidance. With increasing uncertainty avoidance, all aspects of job satisfaction are increasing, except JS6.

According to Chow test and hierarchical regression analysis, national origin of companies is not moderator of regresion between OC2 $\mathrm{i} \mathrm{JSj}$. Hierarchical regression analysis does not support the moderator effect of national origin of companies on relation $\mathrm{OC} 3$ and $\mathrm{JSj}$. According to Chow test national origin of companies is moderator of relation OC3 and JS1 $(\mathrm{F}=2.920)$. The regression coefficient between the independent variable $\mathrm{OC} 3$ and $\mathrm{JSj}$ are significantly negative, for every $j$ except for $j=6$. The increase of the perception of power distance is followed by a increase of negative effect on pay satisfaction. Middle managers from sub-group $\mathrm{F}$ has higher expectations from work conditions, precisely two- way communication, feedback, promotion and availability of resources. Because of that, recognition of practice that is common for domestic companies in Serbia, is followed by a decrease of satisfaction with pay.

By the Chow test, national origin of companies moderates the relation between OC4 and JS1 $(\mathrm{F}=2.414)$. Hierarchical regression analysis does not support the moderator effect of the national origin on the regressions between $\mathrm{OC} 4$ and $\mathrm{JSj}$, where $j=1,2,3,4,5,6,7,8$, 9. Institutional collectivism has its roots in the long period of socialism, during which the principle of egalitarianism was highly valued. Organizations with a high level of institutional collectivism practices encourage and reward the collective distribution of resources and collective action; predominantly as a member of a lifelong group or organization. Middle managers in Serbia consider that personal goals are of less importance than common organizational goals.

By the Chow test, national origin of companies moderates the relation between OC5 and JS1 $(\mathrm{F}=5.477)$ and JS9 $(\mathrm{F}=2.871)$. Hierarchical regression analysis does not support the moderator effect of relation OC5 and JSj. Since in the general sample the regression coefficients between the independent variable OC5 and the dependent variables $\mathrm{JSj}$ are significantly positive, except for $\mathrm{j}=6$, which is significantly negative in sub-group $\mathrm{D}$, the increase of perception of human orientation is followed by the increased satisfaction with all aspects of the job, except for satisfaction with operative procedure. In sub-group D increase of OC5 is followed by increase of pay satisfaction, and makes favourable conditions for active communication in sub-group $\mathrm{F}$. Middle managers in foreign companies in Serbia expecting organizational culture with formal relations and culture oriented to welbeing of company. In domestic companies increase of OC5 is followed by the increased informational flow, flexible communication and important information's about the position of the organization.

According to Chow test results, national origin is moderator of relation OC6 and JS1 $(\mathrm{F}=2.586)$. Hierarchical regression analysis does not support the moderator effect of national origin of companies on relation OC6 and JSj. In the general sample, all regression coefficients between OC6, $\mathrm{JSj}$ are positive and significantly different from zero, except JS6 which is significantly negative in sub-group D. In sub-group F increase of OC6 is 
followed by pay satisfaction. Adequate training programs, feedback and work validation result increase of pay satisfaction. Middle managers in sub-group $\mathrm{F}$ acquire new knowledge that they find useful.

Chow test has shown national origin of companies in Serbia a moderator considering the relation of OC7 and JSj for $\mathrm{j}=1(\mathrm{~F}=-4.647), 5(\mathrm{~F}=3.905), 9$ $(\mathrm{F}=3.297)$. Hierarchical regression analysis has confirmed moderating effect for OC7 and JS1, and JS5. In sub-group F increase of OC7 is followed by faster increases of $\mathrm{JSj}, \mathrm{j}=1,5,9$ than in the case of sub-group D. Middle managers in foreign companies in Serbia are more satisfied with pay, promotion and communication, than middle managers in domestic companies. Satisfaction increase is resulted by promotion based on results, good and harmonious relations with their superiors followed by information's for improvement of performances. According to O'Connell (2001), if employees mean that they are paid fair relatively to the others from the organization, they demonstrate higher level of commitment to the organization and they have pay satisfaction.

Chow test has shown ownership structure of a moderator considering the relation OC8 and JS1 $(\mathrm{F}=3.068)$, but coefficients of correlation are not significantly different from zero. Hierarchical regression analysis has confirmed moderating effect for OC8 and JS9. Before privatization process, in socialistic period, although there were egalitarian tendencies, the role of woman was more connected to household. Like in many other countries, organizational culture in Serbian companies of that time was not favourable for women and their progress and, according to some authors, it was "organizational culture oriented towards men" (Bajdo and Dickson, 2001; Connelly and Rhoton, 1988; Helgesen, 1990; Klenke, 1996; Maier, 1999; Loden, 1985; Marshall, 1993). In domestic companies in Serbia, woman's still face the effect of "'glass ceiling", and also numerous prejudice. For that reason, in sub-group $\mathrm{D}$, increase of OC8 is followed by satisfaction with superiors and communication. On the contrary, in sub-group F, organizational culture with high value of OC8 is expected.

Statistical analysis supported the moderator effect of national origin of companies on the regressions between OC9 and JS1 $(\mathrm{F}=3.768)$, and JS4 $(\mathrm{F}=2.356)$ but coefficients of correlation are not significantly different from zero. Hierarchical regression analysis has confirmed moderating effect for OC9 and JS4, JS8 i JS9. Perhaps the increase of OC9 in the D sub-sample employees produces an additional perception of the lack of harmony in relationships, which causes a decrease in the satisfaction with communication.

\section{CONCLUSION}

Liberalization of the economy and democratization of politics in the early 2000 in Serbia entailed changes in the organizational culture. Nevertheless, several inherited features from the command economy organizational culture are still common for Serbian organizations (for example, a high power distance organizational culture). The research results have showed that national origin of companies represents moderating relation between some dimensions of GLOBE organizational culture and aspects of job satisfaction and that it is a significant factor which determines job satisfaction of middle managers in the companies in Serbia. Our results may help leaders in domestic and foreign companies in Serbia to introduce changes of organizational culture through maximizing or minimizing certain cultural dimensions in order to increase the level of facets of job satisfaction.

Foreign investors should be introduced with some characteristics of organizational culture dimensions in companies in Serbia. That can be very useful for construction of suitable organizational culture that correspond to values of national culture dimensions in companies in Serbia. Better knowledge of this issue is of great importance for foreign investors.

\section{REFERENCES}

Amos, E. A., \& Weathington, B. L. (2008). An Analysis of the Relation between Employee-Organisation Value Congruence and Employee Attitudes. The Journal of Psychology, 142(6), 615-631.

Bajdo, L. M., \& Dickson, M. W. (2001). Perceptions of organizational culture and women's advancement in organizations: A cross-cultural examination. Sex Roles, 45(5/6), 399-414.

Bellou, V. (2010). Organizational culture as a predictor of job satisfaction: the role of gender and age. Career Development International, 15(1), 4-19.

Berry, J. W., \& Ward, C. (2006). Commentary on "redefining interactions across cultures and organizations". Group and Organizational Management, 31, 64-77.

Blyton, P. (2001). The General and the Particular in Cross-National Comparative Research. Applied Psychology: An International Review, 50(4), 590595. 
Brooks, I. (2006). Organisational Behaviour: Individuals, Groups and Organisation (3rd ed.). Prentice Hall: Financial Times.

Chow, G. C. (1960). Tests of equality between sets of coefficients in two linear regression. Econometrica, 26(3), 591-605.

Connelly, M., \& Rhoton, P. (1988). Women in direct sales. In A. Statham, E. Miller, \& H. Mauksch (Eds.), The worth of women's work: A qualitative analysis (pp. 245-264). Albany: State University of New York Press.

Conner, D. (1992). Managing at the speed of change. New York: Villard Books.

Cummings, T. G., \& Worley, C. G. (2005). Organization development and change (8th ed.). Cincinnati, OH: South-Western Thomson.

Deal, T. E., \& Kennedy, A. A. (1982). Corporate Cultures: The Rites and Rituals of Corporate Life. Harmondsworth: Penguin Books.

Denison, D. R. (1996). What is the difference between organizational culture and organizational climate? A native's point of view on a decade of paradigm wars. Academy of Management Review, 21, 619-654.

Dickson, M. W., Den Hartog, D. N., \& Mitchelson, J. K. (2003). Research on leadership in a cross-cultural context: Making progress, and raising new questions. The Leadership Quarterly, 14, 729-768.

Dimitratos, P., Petrou, A., Plakoyiannaki, E., \& Johnson, J. E. (2011). Strategic decision-making processes in internationalization: Does national culture of the focal firm matter? Journal of World Business, 46(2), 194-204.

Fargher, S., Kesting, S., Lange, T., \& Pacheco, G. (2008). Cultural heritage and job satisfaction in Eastern and Western Europe. International Journal of Manpower, 29, 630-650.

Feichtinger, C., \& Fink, G. (1998). The collective culture shock in transition countries theoretical and empirical implications. Leadership and Organization Development Journal, 19(6), 302 308.

Fink, G., \& Holden, N. (2002). Collective culture shock. Contrastive reactions to radical systemic change. EI Working Papers / Europainstitut, 45.

Forschungsinstitut für Europafragen, Vienna: University of Economics and Business.

Gerhart, B. (2008). Cross Cultural Management Research: Assumptions, Evidence, and Suggested Directions. International Journal of Cross Cultural Management, 8(3), 259-274.

Hanke, S. H., \& Krus, N. E. (2012). World Hyperinflations. In R. Parker, \& R. Whaples (Eds.), The Handbook of Major Events in Economic History. Routledge Publishing.

Helgesen, S. (1990). The female advantage: Women's ways of leadership. New York: Doubleday Currency.

Hofstede, G. (1980). Culture's Consequences International Differences in Work-Related Values. (Abridged ed.). Newbury Park: Sage.
Hofstede, G. (1991). Cultures and organizations: software of the mind. McGraw-Hill. London: New York.

Hofstede, G. (2001). Culture's Consequences, Comparing Values, Behaviors, Institutions, and Organizations Across Nations. Thousand Oaks, CA: Sage Publications.

House, R. J., Hanges, P. J., Javidan, M., Dorfman, P. W., \& Gupta. V. (2004). Leadership, culture, and organizations: The GLOBE study of 62 societies. Thousand Oaks, CA: Sage.

House, R. J., Hanges, P. J., Ruiz-Quintanilla, S. A., Dorfman, P. W., Falkus, S. A. \& Ashkanasy, N. M. (1999). Cultural influences on leadership and organizations: Project Globe. In W. H. Mobley, M. J. Gessner and V. Arnold (Ed.), Advances in Global Leadership 2 ed. (pp. 171-233) Bingley, UK: Emerald Group Publishing Ltd.

House, R. J., Javidan, M., \& Dorfman, P. (2001). Project GLOBE: An Introduction. Applied Psychology: An International Review, 50(4), 489505.

House, R. J., Javidan, M., Hanges, P.,\& Dorfman, P. (2002). Understanding Cultures and Implicit Leadership Theories Across the Globe: An Introduction to Project GLOBE. Journal of World Business, 37(1), 3-10.

House, R., Wright, N. S., \& Aditya, R. N. (1997). Cross-cultural research on organizational leadership: A critical analysis and proposed theory. In P.C. Early, M. Erez (Eds.). New Perspectives on International Industrial/Organizational Psychology San Francisco, CA: Lexington Press.

Javidan, M., \& House, R. J. (2001). Cultural Acumen for the Global Manager: Lessons from Project GLOBE. Organizational Dynamics, 29(4), 289-305.

Judge, T. A., Thoresen, C. J., Bono, J. E., \& Patton, G. K. (2001). The Job Satisfaction - Job Performance Relationship: a Qualitative and Quantitative Review. Psychological Bulletin, 127, 376-407.

Klenke, K. (1996). Women and Leadership. A Contextual Perspective. New York: Springer Publishing Company.

Kotter, J. P. (1996). Leading change. Boston: Harvard Business School Press.

Kotter, J., \& Heskett, J. L. (1992). Corporate Culture and Performance. New York: The Free Press.

Kroeber, A. L., Kluckhohn, C., Untereiner, W., \& Meyer, A. G. (1952). Culture: A critical review of concepts and definitions. Harvard University Peabody Museum of American Archeology and Ethnology Papers 47.

Lauzen, M. M., \& Dozier, D. M. (1994). Issues management mediation of linkage between environmental complexity and management of the public relations function. Journal of Public Relations Research, 6(3), 163-184.

Locke, E. A. (1976). The nature and causes of job satisfaction. In M.D. Dunnette (Ed.), Handbook of industrial and organizational psychology. Chicago: Rand McNally. 
Loden, M. (1985). Feminine leadership or how to succeed in business without being one of the boys. New York: Times Books.

Lund, D. B. (2003). Organizational culture and job satisfaction. Journal of Business \& Industrial Marketing, 18(3), 219 - 236.

Maier, M. (1999). On the gendered substructure of organization: Dimensions and dilemmas of corporate masculinity. In G. A. Powell (Ed.). Handbook of gender and work (pp. 69-94.). Thousand Oaks, CA: Sage.

Marshall, J. (1993). Organisational Cultures and Women Managers: Exploring the Dynamics of Resilience. Applied Psychology, 42(4), 313-322.

Meyer, J. P., Stanley, D. J., Herscovitch, L., \& Topolnytsky, L. (2002). Affective, Continuance, and Normative Commitment to the Organization: A Meta-analysis of Antecedents, Correlates, and Consequences. Journal of Vocational Behavior, 61, 20-52.

Milin, P., \& Hadžić, O. (2011). Moderating and Mediating Variables in Psychological Research, in: Lovri, M. (Ed.) International Encyclopedia of Statistical Science (849-852). Berlin: Springer.

Morgan, W. (1977). Investor Owned vs. Publicly Owned Water Agencies: An Evaluation of the Property Rights Theory of the Firm. Water Resources Bulletin, 13, 75-82.

Moynihan, D. P. \& Pandey, S. K. (2007). Finding workable levers over work motivation: Comparing job satisfaction, job involvement, and organizational commitment. Administration \& Society, 39(7), 803 832.

O’Connell, N. L. (2001). Rewarding Employees with Psychic Income Pays Long-Term Dividends, Benefits Quarterly, 17(3), 7-22.

Pasa, S. F., Kabasakal, H., \& Bodur, M. (2001). Society, Organisations, and Leadersip in Turkey. Applied Psychology: An International Review, 50(4), 559589.
Pascale, R., \& Athos, A. (1981). The Art of Japanese Management. London: Penguin Books.

Robins, S., \& Coulter, M., (2005). Management. Belgrade: Data Status. (In Serbian)

Schein, E. H. (1985). Organizational Culture and Leadership: A Dynamic View. San Francisco: Jossey-Bass Publishers, USA.

Schein, E. H. (1990). Innovative cultures and adaptive organisations. Sri Lanka Journal of Development Administration, 7(2), 9-39.

Sempane, M. E., Rieger, H. S., \& Roodt, G. (2002). Job Satisfaction In Relation To Organisational Culture. SA. Journal of Industrial Psychology, 28(2), 23-30.

Silverthorne, C. (2004). The impact of organizational culture and person-organization fit on organizational commitment and job satisfaction in Taiwan.

Leadership \& Organization Development Journal, 25, 592-599.

Smith, P. B. (1992). Organizational Behaviour and National Cultures. British Journal of Management, 3(1), 39-51.

Spector, P. E. (1985). Measurement of human service staff satisfaction: Development of the job satisfaction survey. American Journal of Community Psychology, 13(6), 693-713.

Spector, P. E. (1997). Job satisfaction: Application, assessment, cause, and consequences. Thousand Oaks, CA: Sage Publications, Inc.

Vukonjanski, J., Nikolić, M., Hadžić, O., Terek, E., \& Nedeljković, M. (2012). Relationship between GLOBE organizational culture dimensions, job satisfaction and leader-member exchange in Serbian organizations. Journal for East European Management Studies, 17(3), 333-368.

Wallack, E. J. (1983). Individuals and Organizations: The Cultural Match. Training and Development Journal, 37, 29-36.

Ward, C., Bochner, S., \& Furnham, A. (2001). The psychology of culture shock (2ed.). London: Routledge. 